\title{
Unraveling the Pathogenesis and Etiology of Biliary Atresia
}

\author{
CARA L. MACK AND RONALD J. SOKOL \\ Pediatric Liver Center and Liver Transplantation Program, Section of Pediatric Gastroenterology, Hepatology and \\ Nutrition, Department of Pediatrics [C.M., R.J.S.], Pediatric General Clinical Research Center [R.J.S.], University of \\ Colorado School of Medicine and The Children's Hospital, Denver, Colorado, 80218
}

\begin{tabular}{|c|c|}
\hline \multicolumn{2}{|c|}{ ABSTRACT } \\
\hline $\begin{array}{l}\text { Biliary atresia (BA) is the most common and important } \\
\text { neonatal hepatobiliary disorder. Because current treatment is } \\
\text { inadequate, there is an urgent need to better understand the } \\
\text { etiology and pathogenesis of BA. Two major forms of BA are } \\
\text { recognized: an embryonic form associated with other congenital } \\
\text { anomalies and a perinatal form in which bile ducts were pre- } \\
\text { sumably formed normally but underwent fibro-obliteration in the } \\
\text { perinatal period. There are currently several proposed pathogenic } \\
\text { pathways leading to the phenotype of BA, including an immune } \\
\text { or autoimmune response to a perinatal insult (e.g. cholangiotro- } \\
\text { pic viral infection) and dysregulated embryonic development of } \\
\text { the extra- or intrahepatic biliary system. Recent advances in } \\
\text { developmental biology, genomics and genetics, and cell immu- } \\
\text { nology and biology, coupled with the development of appropriate } \\
\text { animal models, have provided support for these postulated mech- } \\
\text { anisms. Future investigations combining animal model work and } \\
\text { evaluation of clinical specimens holds the promise of identifying }\end{array}$ & 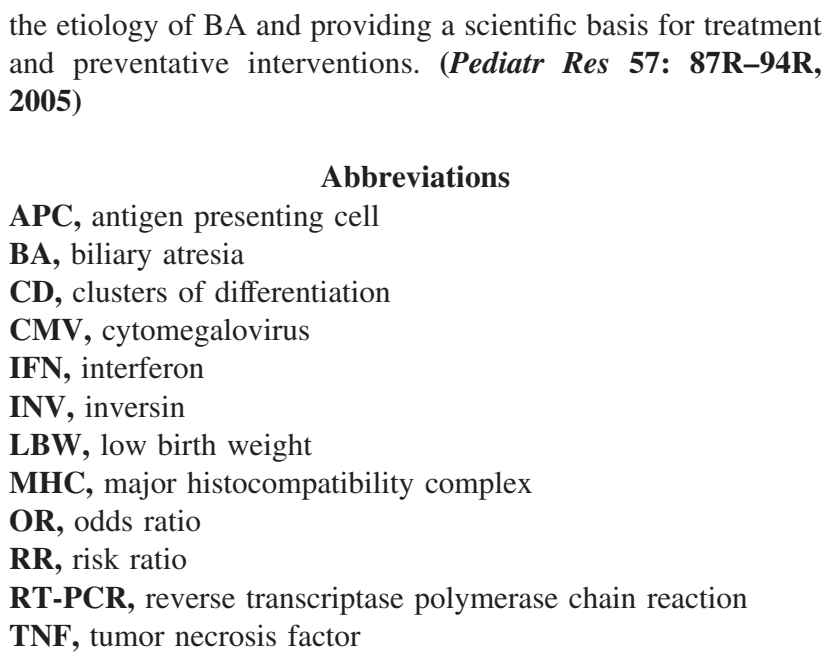 \\
\hline
\end{tabular}

BA is an enigmatic cause of neonatal cholestasis, occurring in 1 in 8,000 to 1 in 18,000 live births and presenting typically within the first months of life with jaundice, acholic stools, and hepatomegaly in an otherwise apparently healthy infant (1). Inflammatory obstruction of the extrahepatic bile ducts is accompanied by a characteristic intrahepatic portal lesion. If diagnosed in the first 2-3 mo of life, hepatic portoenterostomy can restore bile flow from the liver into the intestinal tract in $30-80 \%$ of patients (1-3). Despite successful surgery, progressive inflammation and fibrosis of intrahepatic bile ducts develops to varying degrees in all patients, leading to biliary cirrhosis in the majority of patients. Consequently, $70-80 \%$ of BA patients will eventually require liver transplantation, approximately half in the first $2 \mathrm{y}$ of life (4-6). Thus, BA is the most common indication for liver transplantation in children, responsible for almost $50 \%$ of all pediatric liver transplants. It

Received November 18, 2004; accepted January 3, 2005.

Correspondence: Ronald J. Sokol, M.D., Department of Pediatrics, The Children's Hospital, Box B290, 1056 E. 19th Ave., Denver, CO 80218; e-mail: Sokol.ronald@tchden.org

Supported in part by grants from the National Institutes of Health (R01 DK38446, UO1 DK062453, U54 RR019455, K08 DK60710, and M01 RR00069), the Glaxo-SmithKline Institute for Digestive Health, the Madigan Foundation, and the Abby Bennett Liver Research Fund. should be emphasized that it is the intrahepatic biliary lesion that determines overall prognosis and outcome, thus, this disease is no longer called "extrahepatic" BA. Without a better understanding of the etiology and pathogenesis of this intrahepatic sclerosing cholangitic process in BA, little progress can be expected in improving the nontransplantation outcome of patients. Therefore, there has been a renewed interest in recent years in understanding the underlying pathogenetic mechanisms of BA.

It is now apparent that BA is a phenotype resulting from several pathogenic processes that culminate in obstruction of the biliary tree $(1,7)$. The majority $(80 \%)$ of cases of BA in Western countries are of the perinatal or acquired form. These otherwise normal infants are presumably born with a patent biliary system which undergoes progressive inflammation and fibro-obliteration initiated by a perinatal insult. Although the etiology of this form is not completely understood, proposed precipitating factors include infectious, toxic, vascular, and immune mediators. The second form of BA is associated with other congenital anomalies, most commonly involving abdominal situs, and has been dubbed the embryonic or fetal form. Defective morphogenesis, caused by mutations in genes regulating biliary development, has been proposed in these cases. In 
this review, we will examine recent data supporting the proposed viral and immunologic pathogenesis of the perinatal form of BA, and the potential role for defective genetic regulation of bile duct development in the embryonic form.

\section{VIRAL AND OTHER INFECTIOUS AGENTS}

Epidemiology. Epidemiologic studies support a possible infectious etiology of BA. Multiple studies have demonstrated seasonal clustering of cases suggesting environmental exposure to an infectious agent. A population-based study in metropolitan Atlanta (1968-1993) revealed seasonal clustering of BA diagnoses, with rates 3-fold higher in December through March (OR $=2.63$ for winter compared with spring) (8). Strickland and Shannon (9) found BA case clustering in northeast Texas $\left(\chi^{2}=13.89, p<0.001\right)$ and rural locales $\left(\chi^{2}=\right.$ $25.29, p<0.0001)$ and temporal association with fall compared with the remainder of the year $\left(\chi^{2}=5.96, p=0.015\right)$. A recent study from the state of New York (10) reported seasonal patterns of BA cases that varied by the region of the state. Spring births were at highest risk for BA in New York City and September to November births were at highest risk in other regions of the state. In contrast, epidemiologic studies from Europe have not consistently identified clustering of cases $(5,11)$. Inasmuch as epidemic infections may present at different times of the year in different countries, it is still an open question as to whether case clustering represents a true epidemiologic association.

A second area of epidemiologic research has focused on the birth weight and gestational age of infants with BA. Several studies have revealed an association of low birth weight and shortened gestation with the occurrence of BA. The casecontrolled study from New York state demonstrated an increased risk of BA for LBW preterm and LBW term infants $(\mathrm{OR}=2.92$ and 2.36, respectively, compared with normal weight infants) (10). A similar association was observed in the Atlanta study (8), with term LBW infants having an increased risk compared with term normal birth weight infants $(\mathrm{OR}=$ 3.52). Of greatest interest is a cohort study from Sweden that used the Medical Birth Register of Sweden to assess risk of BA (11). In this study, both small for gestational age (SGA) and preterm status conferred an increased risk of BA. SGA infants had a RR of 5.75 compared with that of appropriately sized infants. Infants born between 22-32 wk of gestation had a RR of 6.75 and those born at 33-36 gestational age had a RR of 2.48 compared with term infants. It is important to note that most in utero viral infections are associated with intrauterine growth retardation or preterm delivery.

Putative viruses. The ongoing search for a putative virus involved in the pathogenesis of BA has led to conflicting findings regarding at least three different viruses: reovirus, rotavirus, and CMV. Interest in reovirus developed after the observation that infection in weanling mice caused extrahepatic bile duct cyst formation and intrahepatic bile duct pathologic features similar to those of BA (12). Serologic studies initially suggested an increased rate of infection with reovirus in infants with BA and neonatal hepatitis $(13,14)$, however, subsequent studies could not confirm these findings $(15,16)$.
Detection of reovirus antigens in the bile duct remnants from an infant Rhesus monkey with BA (17) and from human infants with BA (18) was reported, although the latter findings were not replicated by others (15). Three groups of investigators have examined hepatobiliary tissues removed from infants with BA for reovirus RNA. Steele et al. (19) failed to detect reovirus RNA in archived, formalin-fixed preserved hepatic tissues of 14 BA patients using nested RT- PCR. A recent study from Japan likewise failed to identify reovirus RNA in frozen biliary atresia hepatobiliary tissue, however, the average age at the time of collection of the tissue was 8.7 mo (20). In contrast, Tyler et al. (21) reported the detection of reovirus RNA by RT-PCR in snap-frozen liver, gall bladder, or bile duct remnants from $55 \%$ of cases of BA (average age $2.2 \mathrm{mo}$ ) and in only $8-15 \%$ of controls. The discrepancies among these studies may lie in the age of the patients at the time of sample acquisition, methods of preparation of the tissue, and the use of PCR primers for different reovirus genes. It is also possible that the proposed perinatal viral infection is cleared from the liver within a relatively short period of time, resulting in the inability to detect virus at the time of diagnosis or later, as has been demonstrated in mouse BA models based on viral infection (see below).

Another virus of the Reoviridae family, Group C rotavirus, has received attention. Riepenhoff-Talty et al. (22) examined hepatobiliary tissues of BA patients for RT-PCR evidence of Group $\mathrm{C}$ rotavirus infection. Ten of $18 \mathrm{BA}$ patients at diagnosis and 0 of 12 liver disease control patients showed evidence of rotavirus RNA. In contrast, Bobo et al. (23) failed to detect rotavirus Groups A, B, or C RNA from 10 BA patients and 14 liver disease controls by RT-PCR techniques. However, almost half the patients in that study were over 12 mo of age at the time that tissues were obtained. Rotavirus has also been used to develop a mouse model of BA. Rhesus rotavirus infection produces extrahepatic bile duct obstruction by $2 \mathrm{wk}$ of life despite viral clearance in newborn mice $(24,25)$. Timing of infection was critical, with the highest incidence of cholestasis if infection occurred in the first $12 \mathrm{~h}$ postpartum, after which the incidence of disease diminished (26). It was proposed that the rapidly developing immune system of the mouse over the first week of life may be a factor responsible for the critical window of time in which rotavirus infection may cause biliary disease.

Twenty-three patients with BA were evaluated for CMV by analyzing liver histology, CMV-IgM titers, or CMV viral culture. Five patients $(24 \%)$ were found to be positive for CMV (27). A recent study from Brazil likewise found positive CMV-IgM titers in $28.5 \%$ of patients with BA or choledochal cysts (28). A study from Sweden (29) showed a higher prevalence of CMV antibodies in mothers of BA patients and CMV DNA was present in livers from $50 \%$ of those infants. However, a Canadian group (30) could not demonstrate CMV in bile duct remnants from 12 children with BA. Finally, other viruses have also been examined including papillomavirus $(31,32)$ and herpes virus-6 (32) with similar conflicting results.

In summary, based on the similarities between the neonatal murine models of reovirus and rotavirus and some human studies showing about a 50\% frequency of each of these 
viruses in infants with BA, further study of the roles of these and related viruses in the etiology of BA are warranted. The possible role of CMV, papillomavirus, and herpes virus-6 in BA is likewise unsettled and requires further investigation.

There is scant literature regarding the potential role of bacterial infection as a cause of BA. Tracy et al. (33) investigated the expression of CD14, a monocyte cell surface receptor activated by bacterial endotoxin [lipopolysaccharide (LPS)], on BA liver tissue obtained at the time of portoenterostomy. Intense staining of CD14 was found on sinusoidal and portal tract macrophages in BA tissue and not found in the portal tracts of control specimens. Furthermore, Ahmed et al. (34) compared the in situ expression of CD14 between early and late stages of BA. Almost $70 \%$ of BA specimens at time of portoenterostomy had extensive CD14 expression, especially on sinusoidal Kupffer cells. The CD14 expression was markedly decreased at the time of transplant. They proposed that potential exposure to portally derived LPS leads to CD14 overexpression in BA resulting in macrophage activation with release of pro-inflammatory cytokines and bile duct damage. This mechanism is theoretical at this point and warrants further investigation.

\section{ROLE OF THE IMMUNE SYSTEM IN BILE DUCT INJURY AND OBSTRUCTION}

At the time of diagnosis of BA, the extrahepatic duct remnant is composed of fibrous tissue and scattered lymphocytes (35) whereas intrahepatic ducts are surrounded by a mixed cellular infiltrate composed of lymphocytes, macrophages, and eosinophils (36) (Fig. 1). The role of the immune system in bile duct injury and obstruction is poorly understood at present and is the focus of intense investigation. In the following, the potential role of T-cell-mediated inflammation, macrophage activation, and autoimmune processes are examined.

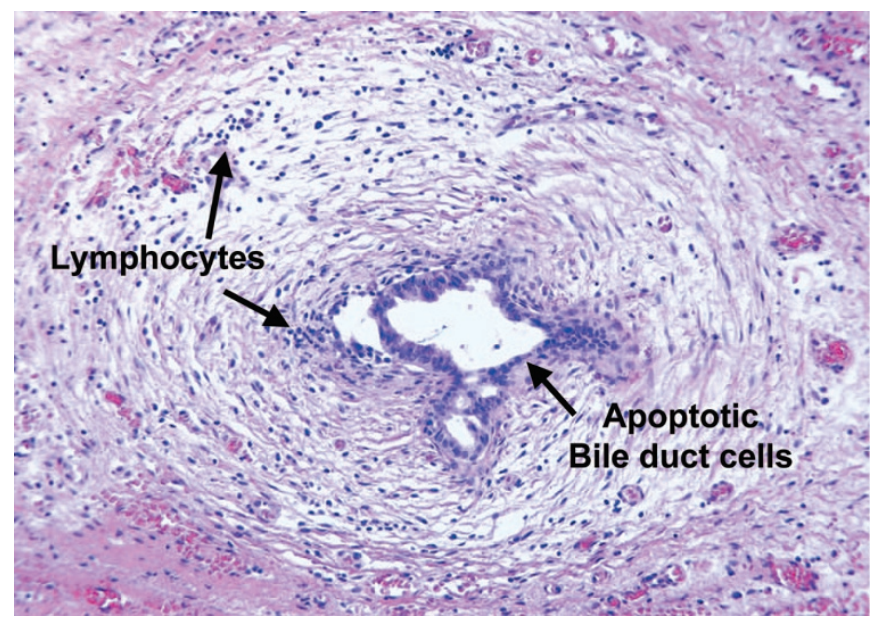

Figure 1. Lesion present in common hepatic duct removed at time of diagnosis of biliary atresia in an 8 wk-old infant without other congenital anomalies. A narrow hepatic duct lumen is still patent, however, bile duct epithelial cells are undergoing apoptosis and disruption. A prominent lymphocytic infiltrate surrounds the remaining duct, with concentric sclerosis developing around the narrowed lumen. (Hematoxylin and eosin, $\times 100$.)
T-cell-mediated inflammation. T-cell activation requires the interaction of the T cell with an APC-bearing antigen in the context of MHC class I (for cytotoxic $\mathrm{CD}^{+} \mathrm{T}$ cells) or $\mathrm{MHC}$ class II (for helper $\mathrm{CD}^{+} \mathrm{T}$ cells). In the inflammatory environment, naïve $\mathrm{CD} 4{ }^{+} \mathrm{T}$ cells differentiate to either Th1 effector cells (driven by IL-12 and producing IFN- $\gamma$, IL-2, TNF- $\beta$, and TNF- $\alpha$ ) or Th2 effector cells (driven by IL-4 and producing IL-4, IL-5, and IL-10). In biliary atresia, T-cell infiltrates surround and invade intrahepatic bile ducts (37), characterized predominantly by $\mathrm{CD} 4^{+} \mathrm{T}$ cells $(38-40), \mathrm{CD}^{+} \mathrm{T}$ cells (41), or a mixture of both (42) (see Fig. 2). Furthermore, increased expression of lymphocyte activation (LFA-1, IL-2 receptor) and proliferation (transferrin receptor) were found in the portal tracts of BA $(40,43)$.

Activated effector $\mathrm{T}$ cells produce cytokines that can directly damage epithelial cells or indirectly damage them through stimulation of other immune cells. Recent investigation has

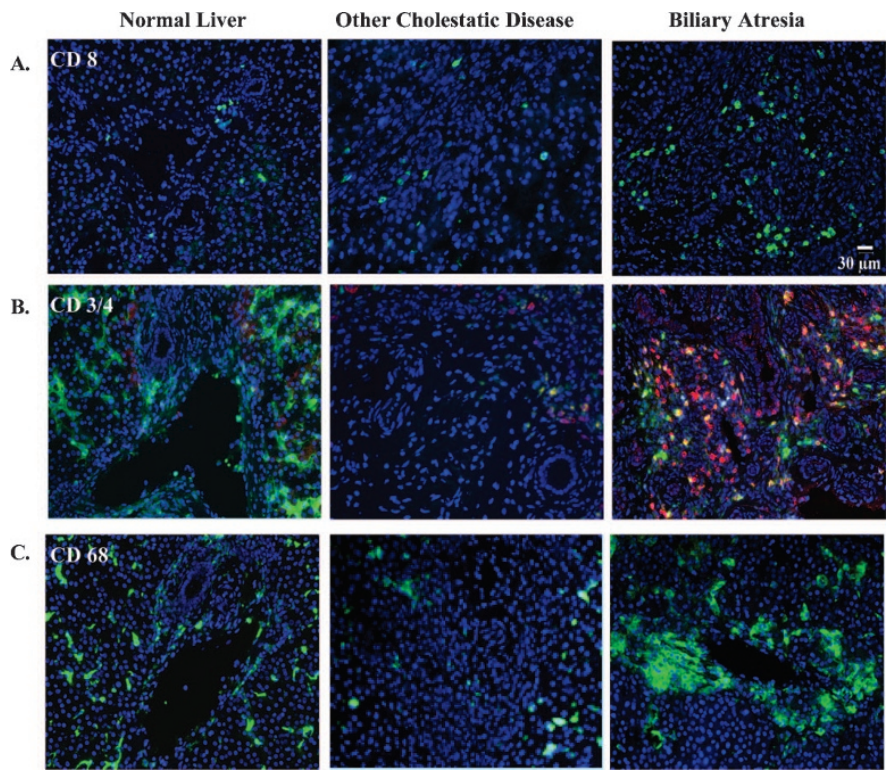

Figure 2. Fluorescent immunohistochemistry reveals an increase in $\mathrm{CD}^{+} \mathrm{T}$ cells, $\mathrm{CD}^{+} / \mathrm{CD}^{+} \mathrm{T}$ cells, and Kupffer cells in the portal tracts in biliary atresia. (Used with permission from Ref. 42.) Frozen sections from normal liver, other neonatal cholestatic liver diseases, and biliary atresia were incubated with MAb, amplified with fluorescein labeled substrate (green), and counterstained with nuclear stain DAPI (blue) (200× magnification). Portal tracts were identified by characteristic vessel formation and bile duct epithelial nuclear staining and verified by serial sections with cytokeratin 7 staining, which is specific for bile duct epithelium (not shown). In normal livers, the portal tracts are seen in the center of each photograph. In other cholestatic diseases and biliary atresia the portal tracts are expanded and encompass the entire field at $200 \times$ magnification. (A) $\mathrm{CD} 8^{+} \mathrm{T}$ cells are more abundant in biliary atresia portal tracts. $(B) \mathrm{CD}^{+}$cell surface expression is found not only on $\mathrm{T}$ cells but also on sinusoidal cells and Kupffer cells. To delineate the CD $4^{+}$ $\mathrm{T}$ cells, the tissue was double stained with anti-CD3 ${ }^{+}$antibody (T-cell-specific marker) (red) and $\mathrm{CD}^{+}$antibody (green). Double-positive cells $\left(\mathrm{CD} 3{ }^{+} \mathrm{CD} 4^{+}\right)$are yellow. There is an increase in the number of $\mathrm{CD} 3{ }^{+} \mathrm{CD} 4^{+}$ cells in biliary atresia portal tracts. The single-stained red cells $\left(\mathrm{CD} 3^{+} \mathrm{CD} 4^{-}\right)$ in biliary atresia reflects the $\mathrm{CD} 8^{+} \mathrm{T}$ cells. Also note the single staining $\mathrm{CD}^{+}$ sinusoidal cells in the parenchyma surrounding the portal tract in normal liver controls. (C) $\mathrm{CD}^{+} 8^{+}$cells (macrophage/Kupffer cells) are increased in the portal tracts of biliary atresia. Note the $\mathrm{CD}^{+} 8^{+}$staining of cells in the parenchyma of controls. Figure adapted from Mack et al., Pediatr Res 56:79-87, Copyright $₫ 2004$ by the International Pediatric Research Foundation, with permission. 
revealed that BA is associated with Th1-cell-mediated portal tract inflammation. We have shown that the periductular immune cells in BA produce IL-12, IFN- $\gamma$, IL-2, and TNF- $\alpha$ (42). This localized inflammatory profile was unique to BA and was not found in other neonatal cholestatic diseases (42). Bezerra et al. (44) used gene expression microarray techniques to analyze BA liver biopsies and observed up-regulation of a number of pro-inflammatory genes (including the Th1 cytokines IFN- $\gamma$ and osteopontin) and down-regulation of Ig genes (suggesting inhibition of Th2 pathway). This laboratory then went on to use the rotavirus-induced murine model of biliary obstruction to demonstrate the importance of IFN- $\gamma$ in the development of this bile duct obstruction (45). IFN- $\gamma$ knock out mice showed increased survival after rotavirus infection and resolution of bile duct obstructive lesions compared with wild-type controls, verifying the critical role of this cytokine in the inflammatory obstructive process. Further investigations of the role of various cytokines in this model and in human BA are warranted in that these may be potential targets for intervention.

There is limited data regarding the identity of the APC responsible for complete T-cell activation in BA. Professional APC include macrophages, dendritic cells, and B cells, whereas nonprofessional APC may include endothelial or epithelial cells (including bile duct epithelium). We and others have shown dramatic increases in portal tract macrophages at the time of diagnosis of BA (discussed below). Furthermore, in our study, portal tract B cells were not increased compared with controls. To date, the potential function of the dendritic cell in the portal tract inflammatory response of BA has not been reported.

Complete T-cell activation requires two signals from the APC: 1) surface expression of self-MHC molecules bearing antigen, which interact with the T-cell receptor; and 2) costimulatory molecules B7-1 and/or B7-2, which interact with CD28 on T cells (46). Competent APC also express intercellular adhesion molecules (ICAM) to provide adhesion of APC to the $\mathrm{T}$ cell. Investigation of the expression of these molecules in BA has been carried out by standard immunohistochemistry techniques. Strong cell surface expression of HLA-DR (MHC class II) was found on Kupffer cells and to a lesser degree on intrahepatic bile duct epithelium $(39,47)$. Furthermore, Kobayashi et al. (48) recently demonstrated increased expression of B7-1 and B7-2 on intrahepatic bile duct epithelium and Kupffer cells in those patients with advanced diseased at presentation. Amplified expression of ICAM on bile duct epithelium of BA liver biopsies has also been described $(38-40)$. Thus, there is accumulating evidence for Kupffer cells and bile duct epithelial cells as potential APC in BA.
Macrophage activation. Portal tracts of BA patients are laden with macrophages $(42,47,49)$ and it appears that the intensity of the macrophage infiltrate correlates with a worse prognosis. Kobayashi et al. (47) found that patients with no bile flow after the portoenterostomy had markedly increased numbers of portal tract macrophages at diagnosis. Davenport $e t$ al. (40) reported prominent macrophage staining in the portal tracts of BA patients. The intensity of the staining correlated with macrophage activation, as evidenced by an increase in the lysosome-rich cytoplasmic volume, and with poor outcome after portoenterostomy.

Activated macrophages produce cytokines IL-12 and IL-18, which function together to promote Th1 cellular differentiation. We demonstrated increased mRNA expression of IL-12 in livers of BA patients at diagnosis (42) and Urushihara et al. (50) reported macrophage activation and increased serum IL-18 in BA patients. Macrophages also secrete cytotoxic cytokines such as TNF- $\alpha$, which are markedly up-regulated in BA (42). TNF- $\alpha$ may also, through receptor binding, induce apoptotic or necrotic cell pathways causing persistent bile duct epithelial injury. To that end, Funaki et al. (51) showed that almost $50 \%$ of intrahepatic bile duct epithelial cells in BA liver were apoptotic compared with only $2.5-3.6 \%$ in the control groups. Another cell death pathway is triggered by the interaction of Fas-ligand (FasL) with Fas-bearing cells. FasL is expressed predominantly on activated $\mathrm{T}$ cells and monocytes/ macrophages. Liu et al. (52) reported that Fas was expressed weakly on bile duct epithelium of both BA and normal liver, however, strong expression was found on $25 \%$ of BA samples and none of controls. Aberrant FasL expression was present in bile duct epithelial cells in approximately $30 \%$ of BA specimens as well as in the majority of portal tract monocytes. Interestingly, FasL expression on bile duct epithelia was associated with poor bile flow postportoenterostomy.

In summary, characterization of the hepatic immune response present at the time of diagnosis of BA (Table 1) forms the basis of the following hypothesis. It is proposed that an initial insult to bile duct epithelia (e.g. a cholangiotropic virus) leads to HLA-DR-restricted Kupffer cell (or bile duct epithelium) presentation of antigens (derived from virus or altered self-antigens on bile duct epithelia) to $\mathrm{CD}^{+}{ }^{+} \mathrm{T}$ cells with subsequent differentiation and proliferation of effector Th1 cells and local release of IL-2, IFN- $\gamma$, and TNF- $\alpha$. IFN- $\gamma$ stimulated release by macrophages of TNF- $\alpha$ and nitric oxide could lead to bile duct epithelial cell apoptosis and necrosis, obstruction, and, ultimately, fibrosis. Continued investigations using animal models and human tissues should help better

Table 1. Immune profile of biliary atresia at presentation

Composition of portal tract infiltrate

Amplified cell surface expression
$\mathrm{CD}^{+}{ }^{\mathrm{T}}$ cell $(38,40), \mathrm{CD}^{+} \mathrm{T}$ cell $(39,40)$, macrophage

$(40,45,47,48)$, NK cells (38)

APC: HLA-DR (36, 37, 45), B7-1 (46), B7-2 (46),

ICAM-1 $(36,37,41)$

Activated T cell: LFA-1 (38), CD25 (38), CD71 (38)

Cell death: Fas (50), FasL (50), TUNEL (49)

IL-2 (40), IFN- $\gamma(40,42)$, TNF- $\alpha$ (40), IL-12 (40), IL-18

(48), IL-8 (42), osteopontin (42) 
define the key factors stimulating and perpetuating this immune response.

BA as an autoimmune disease. The progressive nature of BA, despite initial re-establishment of bile flow with a portoenterostomy, suggests that a persistent autoimmune attack directed at bile ducts may play a role $(53,54)$. In BA, it is possible that the initiator of the bile duct injury is a cholangiotrophic virus, leading to the exposure of altered self bile duct epithelial antigens or previously sequestered self bile duct antigens that would then be recognized as "foreign" and elicit a persistent autoimmune-mediated bile duct injury. It is also possible that molecular mimicry, whereby the virus contains antigens that cross-react with self bile duct epithelial antigens, elicits immune responses against both viral and self antigens $(54,55)$.

The Rose and Witebsky criteria (56) used to define an autoimmune disease include evidence of lymphocytic infiltrate, presence of autoantibodies or evidence on an autoantigen, association with other autoimmune disorders in the patient or family, and HLA association. There is clearly a predominance of lymphocytes in BA liver tissue. The search for autoantibodies has yielded preliminary results. Vasiliauskas et al. (57) reported that 10 of 11 patients with BA were positive for serum IgG and IgM antineutrophil cytoplasmic antibodies (ANCA), with higher levels of the IgM-ANCA in BA patients compared with children and adults with other liver diseases. At our center, Burch et al. (58) examined lupus autoantibodies in mothers of children with BA and idiopathic neonatal hepatitis to test the hypothesis that maternal transfer of autoantibodies might be involved in liver and bile duct injury in the infant. Low titer anti-Rho antibodies were more prevalent in mothers of infants with BA and idiopathic neonatal hepatitis than in controls, and low titer antinuclear antibodies were more common in mothers of infants with liver disease. To date, there have been no studies addressing the frequency of other autoimmune diseases in BA patients or in other family members. Interestingly, children with BA who undergo liver transplant have a $2.5 \%$ risk of developing de novo autoimmune hepatitis after transplantation $(59,60)$, perhaps indicating a genetic predisposition to autoimmune disease.

Multiple inherited genetic polymorphisms are believed to contribute to autoimmune disease susceptibility; the strongest associations are with HLA genes, especially HLA-DR, -DQ, or -DP (MHC-class II equivalent) (46). For example, increased frequencies of HLA B8 and DR3 are found in patients with primary sclerosing cholangitis $(61,62)$ and HLA A1-B8-DR3 and DR4 are risk factors for autoimmune hepatitis (63). Investigators have explored the possibility of a link between HLA type and BA with conflicting results. Rosenthal et al. (64) suggested an increased frequency of HLA-Cw4/7 in BA. Silveira et al. (65) reported a significantly higher prevalence of HLA-B12 and A-Kader et al. (66) from Egypt observed significant increases in both HLA B8 and DR3. Only 55 and 18 BA patients were analyzed, respectively, and serological phenotype techniques were used. More recently, DNA genotyping has been adapted for HLA typing, yielding a greater number of HLA loci and alleles to be tested with much greater accuracy. Using DNA genotyping, Donaldson et al. (67) found no HLA associations in $101 \mathrm{BA}$ patients from the United Kingdom. It is clear that a large, multicentered study of HLA genotyping (including high resolution of HLA-class II) and a sample size calculated to generate statistically sound results is needed.

\section{MORPHOGENESIS GENES AND BILIARY ATRESIA}

Laterality genes. It has been proposed that the embryonic form of BA is caused by defective development of the biliary tree. The association of anomalies of visceral organ symmetry with BA (the polysplenia or BA splenic malformation syndrome) implies that genes that control normal situs development are also key regulators of normal extrahepatic bile duct development. The initial animal model that suggested this class of genes was that of a recessive insertional mutation in the proximal region of mouse chromosome 4 or complete deletion of the inversion (inv) gene in the mouse $(68,69)$. This mouse model, with laterality defects in abdominal organ placement, also included anomalous development of the hepatobiliary system. Therefore, the human $I N V$ gene, recently mapped by Schon and colleagues (70), was examined in 64 patients with heterotaxia. No mutations were found in seven patients with BA and various congenital laterality defects, making it unlikely that the $I N V$ gene is responsible for the majority of embryonic cases of BA. Interestingly, recessive mutations in $I N V$ were recently described in children with nephronophthisis type 2 (71), a disease in which abnormal biliary development has been described (72). Moreover the INV protein was found to interact with nephrocystin, both being located on the primary cilia of renal tubular cells (71). Thus, gene products with localization to the mechanosensory primary cilium of renal tubular cells and cholangiocytes may produce aberrant biliary development with predominance of ductal plate malformation. In this regard, there is subset of patients with BA who have a ductal plate malformation-like lesion in portal tracts, and who are believed to have a worse prognosis (73). It remains to be seen whether mutations or polymorphisms of genes that code for proteins regulating functions of the primary cilia will play a role in the pathogenesis of BA.

More than 30 other mammalian proteins have now been described that are involved in establishment of left-right patterning during embryogenesis, although few have been examined in BA. Bamford et al. (74) analyzed the $C F C l$ gene (which encodes the human CRYPTIC protein) in genomic DNA from 144 cases of familial and sporadic cases of laterality defects. Heterozygous mutations were identified in nine patients, including one with BA and the polysplenia syndrome. Jacquemin et al. (75) subsequently found heterozygous gene mutations in two brothers with laterality defects, one of whom had BA, which were inherited from their unaffected mother. Thus, heterozygous $C F C l$ mutations may predispose to BA, but also appear to require a second genetic or environmental factor to produce the BA phenotype. The CRYPTIC protein acts as a cofactor in the Nodal pathway that determines leftright axis development potentially through its function in the transforming growth factor beta signaling pathway (75).

ZIC3 encodes a zinc finger transcription factor that translocates to the nucleus and influences left-right axis determina- 
tion. In 2004, Ware et al. (76) reported eight ZIC3 mutations in 194 heterotaxia patient samples and calculated that mutations in this gene were responsible for approximately $1 \%$ of patients with sporadic heterotaxy. Among the patients with mutations and complex congenital heart disease, two had BA, one abnormal liver lobulation, and one cholelithiasis and cholecystitis. Thus, there appears to be an association between mutations in this gene and isolated cases of BA and heterotaxia. Evaluation of ZIC3 in a larger population of patients with BA, with and without other congenital anomalies, will be of interest. Other human genes that determine laterality (LEFTYA and ACVR2B) and cell adhesion (CRELD1 and NKX2.5) have been associated with a small percentage of human situs defects (76). Interestingly, Zhang et al. (77) recently reported no differences in mRNA expression of a panel of laterality genes in liver from embryonic versus perinatal cases of BA. Future investigations of these and other genes in coming years may shed light on whether inherited or somatic mutations or deletions are responsible for individual cases of BA.

Intrahepatic bile duct development and BA. Normal development of intrahepatic bile ducts is controlled by interactions between mesenchyme and portal venous radicals, forming the ductal plate. The ductal plate is derived from a subset of hepatoblasts that differentiate into a single-layered ring of biliary precursor cells that surround portal venous branches and their encompassing mesenchyme within the liver (reviewed in 78,79 ), occurring by $5 \mathrm{wk}$ gestation. Remodeling of the ring of cells occurs over the next 6-7 wk. This single layer of cells becomes partly bi-layered followed by the development of focal dilated areas between the two cell layers, which soon give rise to the portal tract bile ducts. Abnormal remodeling of the ductal plate leads to the ductal plate malformation that is present in congenital hepatic fibrosis and other bile duct dysplasias. Interestingly, a number of infants with BA show evidence of the ductal plate malformation on liver biopsy (73). Polymorphisms in HNF6, HNF1-B, JAGGED1, PKDH1, or other related genes that regulate remodeling of the ductal plate (80-82) could act as susceptibility factors or modifier genes necessary, but not sufficient, for the development of BA. In this regard, Kohsaka et al. (83) identified JAGGEDl missense mutations in 9 of 102 patients with BA, who had no phenotypic features of Alagille syndrome. Remarkably, prognosis was worse in the group with mutations, suggesting that JAGGEDI could be a modifying factor in BA. However, other factors known to influence prognosis in BA, such as age at time of portoenterostomy, were not elucidated in the report. Thus, it is not clear whether these patients had an unusual form of BA caused by mutations in JAGGED1, whether the phenotype reported was a unique presentation of Alagille syndrome, or whether the gene functioned as a modifying factor in BA. These observations remain to be confirmed but support the possibility that predisposition to BA may have a genetic basis.

Just how a defect in ductal plate remodeling could lead to atresia of the extrahepatic biliary tree is not intuitively obvious. The hypothesis of Tan and colleagues may shed light on this quandary. Tan et al. (84) have demonstrated the presence of extravasated bile in bile duct remnants of BA patients, proposed to have originated from breaks in the biliary mucosa at the porta hepatitis. The supposition is that there is a vulnerable stage of human biliary development between 11 and $13 \mathrm{wk}$ of gestation, when failure of remodeling of the ductal plate structures could lead to disturbances in the normal development of the mesenchymal cuff that surrounds developing hilar bile ducts. Alternatively, connections of the hepatic ducts (derived from tubulization of the ductal plate structures) with the extrahepatic bile ducts could be perturbed. Either of these alterations could potentially cause hilar bile ducts to rupture at the initiation of bile flow at 12-13 wk of gestation. Extravasated bile, with its detergent properties, into adjacent periductal tissues would then lead to protracted inflammation and sclerosis in the submucosa, causing secondary obliteration and obstruction of the more distal extrahepatic bile duct. This hypothetical mechanism was first described by Rolleston and Hayne (85) in 1901, who coined the term "descending cholangitis."

\section{SUMMARY}

Recent advances in developmental biology, genetics, genomics, and cell biology have opened the door to a better understanding of the underlying mechanisms causing BA. A unifying hypothesis is provided in Figure 3, illustrating the proposed stereotypic response of the infant biliary tree to a variety of insults, both prenatal and postnatal. Embryonic BA may be the result of mutations in genes controlling normal bile

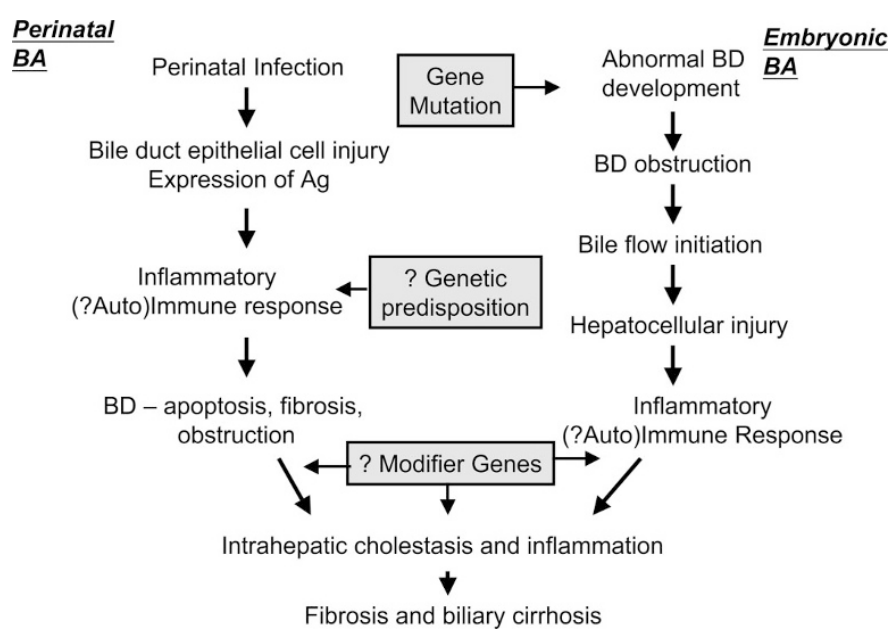

Figure 3. Proposed pathways for pathogenesis of two forms of BA. Perinatal BA may develop when a perinatal insult, such as a cholangiotropic viral infection, triggers bile duct $(B D)$ epithelial cell injury and exposure of self- or neo-antigens that elicit a subsequent immune response. The resulting inflammation induces apoptosis and necrosis of extrahepatic BD epithelium resulting in fibro-obliteration of the lumen and obstruction of the BD. Intrahepatic bile ducts may also be targets in the ongoing TH1 immune (autoimmune?) attack and the cholestatic injury, resulting in progressive portal fibrosis culminating in biliary cirrhosis. Embryonic BA may be the result of mutations in genes controlling normal bile duct formation or differentiation, which secondarily induces an inflammatory/immune response within the common bile duct and liver after the initiation of bile flow at approximately 11-13 wk of gestation. Secondary hepatocyte and intrahepatic bile duct injury ensue either as a result of cholestatic injury or as targets for the immune (autoimmune?) response that develops. The end result is intrahepatic cholestasis and portal tract fibrosis, culminating in biliary cirrhosis. Other major factors may be the role played by genetic predisposition to autoimmunity and modifier genes that determine the extent and type of cellular and immune response and the generation of fibrosis. 
duct formation or differentiation, which secondarily induces an inflammatory response within the liver that injures and scleroses intrahepatic bile ducts. Perinatal BA may develop when a perinatal insult triggers bile duct epithelial injury and a subsequent immune response that damages both extrahepatic and intrahepatic bile ducts. Other major factors may be the role played by genetic predisposition to autoimmunity and modifier genes that determine the extent and type of cellular and immune response and the generation of fibrosis. Over coming years, multi-institutional and interdisciplinary collaborations will set the stage to provide the needed patient samples and technology to unravel the pathogenesis of this uniquely neonatal disorder, with the hope of developing a scientific rationale for innovative treatment and preventative approaches.

\section{REFERENCES}

1. Sokol RJ, Mack C, Narkewicz MR, Karrer FM 2003 Pathogenesis and outcome of biliary atresia: current concepts. J Pediatr Gastroenterol Nutr 37:4-21

2. Ohi R 2000 Biliary atresia. A surgical perspective. Clin Liver Dis 4:779-804

3. Schweizer P 1986 Treatment of extrahepatic biliary atresia: results and long-term prognosis after hepatic portoenterostomy. Pediatr Surg 1:30-36

4. Karrer FM, Bensard DD 2000 Neonatal cholestasis. Semin Pediatr Surg 9:166-169

5. Chardot C, Carton M, Spire-Bendelac N, Le Pommelet C, Golmard JL, Auvert B 1999 Epidemiology of biliary atresia in France: a national study 1986-96. J Hepatol 31:1006-1013

6. Karrer FM, Price MR, Bensard DD, Sokol RJ, Narkewicz MR, Smith DJ, Lilly JR 1996 Long-term results with the Kasai operation for biliary atresia. Arch Surg 131:493-496

7. Perlmutter DH, Shepherd RW 2002 Extrahepatic biliary atresia: a disease or a phenotype? Hepatology 35:1297-1304

8. Yoon PW, Bresee JS, Olney RS, James LM, Khoury MJ 1997 Epidemiology of biliary atresia: a population-based study. Pediatrics 99:376-382

9. Strickland AD, Shannon K 1982 Studies in the etiology of extrahepatic biliary atresia: time-space clustering. J Pediatr 100:749-753

10. Caton AR, Druschel CM, McNutt LA 2004 The epidemiology of extrahepatic biliary atresia in New York State, 1983-98. Paediatr Perinat Epidemiol 18:97-105

11. Fischler B, Haglund B, Hjern A 2002 A population-based study on the incidence and possible pre- and perinatal etiologic risk factors of biliary atresia. J Pediatr 141:217222

12. Bangaru B, Morecki R, Glaser JH, Gartner LM, Horwitz MS 1980 Comparative studies of biliary atresia in the human newborn and reovirus-induced cholangitis in weanling mice. Lab Invest 43:456-462

13. Morecki R, Glaser JH, Cho S, Balistreri WF, Horwitz MS 1982 Biliary atresia and reovirus type 3 infection. N Engl J Med 307:481-484

14. Glaser JH, Balistreri WF, Morecki R 1984 Role of reovirus type 3 in persisten infantile cholestasis. J Pediatr 105:912-915

15. Brown WR, Sokol RJ, Levin MJ, Silverman A, Tamaru T, Lilly JR, Hall RJ, Cheney M 1988 Lack of correlation between infection with reovirus 3 and extrahepatic biliary atresia or neonatal hepatitis. J Pediatr 113:670-676

16. Dussaix E, Hadchouel M, Tardieu M, Alagille D 1984 Biliary atresia and reovirus type 3 infection. N Engl J Med 310:658

17. Rosenberg DP, Morecki R, Lollini LO, Glaser J, Cornelius CE 1983 Extrahepatic biliary atresia in a rhesus monkey (Macaca mulatta). Hepatology 3:577-580

18. Morecki R, Glaser JH, Johnson AB, Kress Y 1984 Detection of reovirus type 3 in the porta hepatis of an infant with extrahepatic biliary atresia: ultrastructural and immunocytochemical study. Hepatology 4:1137-1142

19. Steele MI, Marshall CM, Lloyd RE, Randolph VE 1995 Reovirus 3 not detected by reverse transcriptase-mediated polymerase chain reaction analysis of preserved tissue from infants with cholestatic liver disease. Hepatology 21:697-702

20. Saito T, Shinozaki K, Matsunaga T, Ogawa T, Etoh T, Muramatsu T, Kawamura K, Yoshida H, Ohnuma N, Shirasawa H 2004 Lack of evidence for reovirus infection in tissues from patients with biliary atresia and congenital dilatation of the bile duct. J Hepatol 40:203-211

21. Tyler KL, Sokol RJ, Oberhaus SM, Le M, Karrer FM, Narkewicz MR, Tyson RW, Murphy JR, Low R, Brown WR 1998 Detection of reovirus RNA in hepatobiliary tissues from patients with extrahepatic biliary atresia and choledochal cysts. Hepatology 27:1475-1482

22. Riepenhoff-Talty M, Gouvea V, Evans MJ, Svensson L, Hoffenberg E, Sokol RJ, Uhnoo I, Greenberg SJ, Schakel K, Zhaori G, Fitzgerald J, Chong S, el-Yousef M, Nemeth A, Brown M, Piccoli D, Hyams J, Ruffin D, Rossi T 1996 Detection of group $\mathrm{C}$ rotavirus in infants with extrahepatic biliary atresia. J Infect Dis 174:8-15

23. Bobo L, Ojeh C, Chiu D, Machado A, Colombani P, Schwarz K 1997 Lack of evidence for rotavirus by polymerase chain reaction/enzyme immunoassay of hepatobiliary samples from children with biliary atresia. Pediatr Res 41:229-234

24. Riepenhoff-Talty M, Schaekel K, Clark HF, Mueller W, Uhnoo I, Rossi T, Fisher J, Ogra PL 1993 Group A rotaviruses produce extrahepatic biliary obstruction in orally inoculated newborn mice. Pediatr Res 33:394-399
25. Petersen C, Biermanns D, Kuske M, Schakel K, Meyer-Junghanel L, Mildenberger H 1997 New aspects in a murine model for extrahepatic biliary atresia. J Pediatr Surg 32:1190-1195

26. Czech-Schmidt G, Verhagen W, Szavay P, Leonhardt J, Petersen C 2001 Immunological gap in the infectious animal model for biliary atresia. J Surg Res 101:62-67

27. Tarr PI, Haas JE, Christie DL 1996 Biliary atresia, cytomegalovirus, and age at referral. Pediatrics 97:828-831

28. Oliveira NL, Kanawaty FR, Costa SC, Hessel G 2002 Infection by cytomegalovirus in patients with neonatal cholestasis. Ar Qgastroenterol 39:132-136

29. Fischler B, Ehrnst A, Forsgren M, Orvell C, Nemeth A 1998 The viral association of neonatal cholestasis in Sweden: a possible link between cytomegalovirus infection and extrahepatic biliary atresia. J Pediatr Gastroenterol Nutr 27:57-64

30. Jevon GP, Dimmick JE 1999 Biliary atresia and cytomegalovirus infection: a DNA study. Pediatr Dev Pathol 2:11-14

31. Drut R, Drut RM, Gomez MA, Cueto Rua E, Lojo MM 1998 Presence of human papillomavirus in extrahepatic biliary atresia. J Pediatr Gastroenterol Nutr 27:530535

32. Domiati-Saad R, Dawson DB, Margraf LR, Finegold MJ, Weinberg AG, Rogers BB 2000 Cytomegalovirus and human herpesvirus 6 , but not human papillomavirus, are present in neonatal giant cell hepatitis and extrahepatic biliary atresia. Pediatr Dev Pathol 3:367-373

33. Tracy TF Jr, Dillon P, Fox ES, Minnick K, Vogler C 1996 The inflammatory response in pediatric biliary disease: macrophage phenotype and distribution. J Pediatr Surg $1: 121-125$

34. Ahmed AF, Nio M, Ohtani H, Nagura H, Ohi R 2001 In situ CD14 expression in biliary atresia: comparison between early and late stages. J Pediatr Surg 36:240-243

35. Gosseye S, Otte JB, De Meyer R, Maldague P 1977 A histological study of extrahepatic biliary atresia. Acta Paediatr Belg 30:85-90

36. Bill AH, Haas JE, Foster GL 1977 Biliary Atresia: histopathologic observations and reflections upon its natural history. J Pediatr Surg 12:977-982

37. Ohya T, Fujimoto T, Shimomura H, Miyano T 1995 Degeneration of intrahepatic bile duct with lymphocyte infiltration into biliary epithelial cells in biliary atresia. J Pediatr Surg 30:515-518

38. Dillon PW, Belchis D, Minnick K, Tracy T 1997 Differential expression of the major histocompatibility antigens and ICAM-1 on bile duct epithelial cells in biliary atresia. Tohoku J Exp Med 181:33-40

39. Broome U, Nemeth A, Hultcrantz R, Scheynius A 1997 Different expression of HLA-DR and ICAM-1 in livers from patients with biliary atresia and Byler's disease. J Hepatol 26:857-862

40. Davenport M, Gonde C, Redkar R, Koukoulis G, Tredger M, Mieli-Vergani G, Portmann B, Howard ER 2001 Immunohistochemistry of the liver and biliary tree in extrahepatic biliary atresia. J Pediatr Surg 36:1017-1025

41. Ahmed AF, Ohtani H, Nio M, Funaki N, Shimaoka S, Nagura H, Ohi R 2001 CD8+ $\mathrm{T}$ cells infiltrating into bile ducts in biliary atresia do not appear to function as cytotoxic T cells: a clinicopathological analysis. J Pathol 193:383-389

42. Mack CL, Tucker RM, Sokol RJ, Karrer FM, Kotzin BL, Whitington PF, Miller SD 2004 Biliary atresia is associated with CD4+ Th1 cell-mediated portal tract inflammation. Pediatr Res 56:79-87

43. Dillon P, Belchis D, Tracy T, Cilley R, Hafer L, Krummel T 1994 Increased expression of intercellular adhesion molecules in biliary atresia. Am J Pathol 145:263-267

44. Bezerra JA, Tiao G, Ryckman FC, Alonso M, Sabla GE, Shneider B, Sokol RJ, Aronow BJ 2002 Genetic induction of proinflammatory immunity in children with biliary atresia. Lancet 360:1653-1659

45. Shivakumar P, Campbell KM, Sabla GE, Miethke A, Tiao G, McNeal MM, Ward RL, Bezerra JA 2004 Obstruction of extrahepatic bile ducts by lymphocytes is regulated by IFN-gamma in experimental biliary atresia. J Clin Invest 114:322-329

46. Abbas AK, Lichtman AH, Pober JS 2000 Cellular and Molecular Immunology. WB Saunders, Philadelphia, pp vii, 553

47. Kobayashi H, Puri P, O’Briain DS, Surana R, Miyano T 1997 Hepatic overexpression of MHC class II antigens and macrophage-associated antigens (CD68) in patients with biliary atresia of poor prognosis. J Pediatr Surg 32:590-593

48. Kobayashi H, Li Z, Yamataka A, Lane GJ, Miyano T 2003 Role of immunologic costimulatory factors in the pathogenesis of biliary atresia. J Pediatr Surg 38:892-896

49. Tracy TF Jr, Dillon P, Fox ES, Minnick K, Vogler C 1996 The inflammatory response in pediatric biliary disease: macrophage phenotype and distribution. J Pediatr Surg 31:121-126

50. Urushihara N, Iwagaki H, Yagi T, Kohka H, Kobashi K, Morimoto Y, Yoshino T, Tanimoto T, Kurimoto M, Tanaka N 2000 Elevation of serum interleukin-18 levels and activation of Kupffer cells in biliary atresia. J Pediatr Surg 35:446-449

51. Funaki N, Sasano H, Shizawa S, Nio M, Iwami D, Ohi R, Nagura H 1998 Apoptosis and cell proliferation in biliary atresia. J Pathol 186:429-433

52. Liu C, Chiu JH, Chin T, Wang LS, Li AF, Chow KC, Wei C 2000 Expression of fas ligand on bile ductule epithelium in biliary atresia - a poor prognostic factor. J Pediatr Surg 35:1591-1596

53. Schreiber RA, Kleinman RE 1993 Genetics, immunology, and biliary atresia: an opening or a diversion? J Pediatr Gastroenterol Nutr 16:111-113

54. Sokol RJ, Mack C 2001 Etiopathogenesis of biliary atresia. Semin Liver Dis 21:517-524

55. Eagar T, Tompkins S, Miller S 2001 Helper T-cell subsets and control of the inflammatory response. In: Rich R, Fleisher T, Shearer W, Kotzin B, Schroeder H Jr (eds) Clinical Immunology Principles and Practice. Mosby, London, pp 16.11-16.12

56. Rose NR, Bona C 1993 Defining criteria for autoimmune diseases (Witebsky's postulates revisited). Immunol Today 14:426-430

57. Vasiliauskas E, Targan S, Cobb L, Vidrich A, Rosenthal P 1995 Biliary atresia-an autoimmune disorder? Hepatology 22:87 
58. Burch J, Sokol RJ, Narkewicz MR, Reichlin M, Frank B, Marchbank A, Lee L 2000 The Role of maternal antibodies in cholestatic liver disease in infants: a new isolated finding in neonatal lupus? J Pediatr Gastroenterol Nutr 31(suppl 2):S108

59. Kerkar N, Hadzic N, Davies ET, Portmann B, Donaldson PT, Rela M, Heaton ND, Vergani D, Mieli-Vergani G 1998 De-novo autoimmune hepatitis after liver transplantation. Lancet 351:409-413

60. Hernandez HM, Kovarik P, Whitington PF, Alonso EM 2001 Autoimmune hepatitis as a late complication of liver transplantation. J Pediatr Gastroenterol Nutr 32:131136

61. Chapman RW 1991 Role of immune factors in the pathogenesis of primary sclerosing cholangitis. Semin Liver Dis 11:1-4

62. Donaldson PT, Manns MP 1999 Immunogenetics of liver disease. In: Benhamou J-P, McIntyre N, Rizetto M, Rodes J (eds) Oxford Textbook of Clinical Hepatology. Oxford University Press, Oxford, pp 173-188

63. Manabe K, Donaldson PT, Underhill JA, Doherty DG, Mieli-Vergani G, McFarlane IG, Eddleston AL, Williams R 1993 Human leukocyte antigen A1-B8-DR3-DQ2DPB1*0401 extended haplotype in autoimmune hepatitis. Hepatology 18:1334-1337

64. Rosenthal P, Woolf GM, Tyan DB 1995 A striking association between HLA-C and biliary atresia. Gastroenterology 108:A1158

65. Silveira TR, Salzano FM, Donaldson PT, Mieli-Vergani G, Howard ER, Mowat AP 1993 Association between HLA and extrahepatic biliary atresia. J Pediatr Gastroenterol Nutr 16:114-117

66. A-Kader HH, El-Ayyouti M, Hawas S, Abdalla A, Al-Tonbary Y, Bassiouny M, Boneberg A, El-Sallab S 2002 HLA in Egyptian children with biliary atresia. J Pediat 141:432-433

67. Donaldson PT, Clare M, Constantini PK, Hadzic N, Mieli-Vergani G, Howard E, Kelley D 2002 HLA and cytokine gene polymorphisms in biliary atresia. Liver 22:213-219

68. Mazziotti MV, Willis LK, Heuckeroth RO, LaRegina MC, Swanson PE, Overbeek PA, Perlmutter DH 1999 Anomalous development of the hepatobiliary system in the Inv mouse. Hepatology 30:372-378

69. Yokoyama T, Copeland NG, Jenkins NA, Montgomery CA, Elder FF, Overbeek PA 1993 Reversal of left-right asymmetry: a situs inversus mutation. Science 260:679-682

70. Schon P, Tsuchiya K, Lenoir D, Mochizuki T, Guichard C, Takai S, Maiti AK, Nihei H, Weil J, Yokoyama T, Bouvagnet P 2002 Identification, genomic organization, chromosomal mapping and mutation analysis of the human INV gene, the ortholog of a murine gene implicated in left-right axis development and biliary atresia. Hum Genet 110:157-165

71. Otto EA, Schermer B, Obara T, O'Toole JF, Hiller KS, Mueller AM, Ruf RG, Hoefele J, Beekmann F, Landau D, Foreman JW, Goodship JA, Strachan T, Kispert A, Wolf MT, Gagnadoux MF, Nivet H, Antignac C, Walz G, Drummond IA, Benzing
T, Hildebrandt F 2003 Mutations in INVS encoding inversin cause nephronophthisis type 2 , linking renal cystic disease to the function of primary cilia and left-right axis determination. Nat Genet 34:413-420

72. Johnson CA, Gissen P, Sergi C 2003 Molecular pathology and genetics of congenital hepatorenal fibrocystic syndromes. J Med Genet 40:311-319

73. Low Y, Vijayan V, Tan CE 2001 The prognostic value of ductal plate malformation and other histologic parameters in biliary atresia: an immunohistochemical study. J Pediatr 139:320-322

74. Bamford RN, Roessler E, Burdine RD, Saplakoglu U, dela Cruz J, Splitt M, Goodship JA, Towbin J, Bowers P, Ferrero GB, Marino B, Schier AF, Shen MM, Muenke M, Casey B 2000 Loss-of-function mutations in the EGF-CFC gene CFC1 are associated with human left-right laterality defects. Nat Genet 26:365-369

75. Jacquemin E, Cresteil D, Raynaud N, Hadchouel M 2002 CFCI gene mutation and biliary atresia with polysplenia syndrome. J Pediatr Gastroenterol Nutr 34:326-327

76. Ware SM, Peng J, Zhu L, Fernbach S, Colicos S, Casey B, Towbin J, Belmont JW 2004 Identification and functional analysis of ZIC3 mutations in heterotaxy and related congenital heart defects. Am J Hum Genet 74:93-105

77. Zhang DY, Sabla G, Shivakumar P, Tiao G, Sokol RJ, Mack C, Shneider BL, Aronow B, Bezerra JA 2004 Coordinate expression of regulatory genes differentiates embryonic and perinatal forms of biliary atresia. Hepatology 39:954-62

78. Vijayan V, Tan CE 1997 Developing human biliary system in three dimension. Anat Rec 249:389-398

79. Lemaigre FP 2003 Development of the biliary tract. Mech Dev 120:81-87

80. Clotman F, Lannoy VJ, Reber M, Cereghini S, Cassiman D, Jacquemin P, Roskams T, Rousseau GG, Lemaigre FP 2002 The onecut transcription factor HNF6 is required for normal development of the biliary tract. Development 129:1819-1828

81. Coffinier C, Gresh L, Fiette L, Tronche F, Schutz G, Babinet C, Pontoglio M, Yaniv M, Barra J 2002 Bile system morphogenesis defects and liver dysfunction upon targeted deletion of HNF1beta. Development 129:1829-1838

82. Clotman F, Libbrecht L, Gresh L, Yaniv M, Roskams T, Rousseau GG, Lemaigre FP 2003 Hepatic artery malformations associated with a primary defect in intrahepatic bile duct development. J Hepatol 39:686-692

83. Kohsaka T, Yuan ZR, Guo SX, Tagawa M, Nakamura A, Nakano M, Kawasasaki H, Inomata Y, Tanaka K, Miyauchi J 2002 The significance of human jagged 1 mutations detected in severe cases of extrahepatic biliary atresia. Hepatology 36:904-912

84. Tan CE, Moscoso GJ 1994 The developing human biliary system at the porta hepatis level between 11 and 25 weeks of gestation: a way to understanding biliary atresia. Part 2. Pathol Int 44:600-610

85. Rolleston HD, Hayne LB 1901 A case of congenital hepatic cirrhosis with obliterative cholangitis (congenital obliteration of the bile ducts). BMJ 1:758-760 